J-SANAK: Jurnal Kajian Anak

(p-ISSN: 2686-5343 |e-ISSN: 2715-7989)

Vol. (1)(2), (Januari-Juni)(2020), (Halaman)(62-77)

DOI: https://doi.org/10.24127/j-sanak.v1i02.233

\title{
UPAYA GURU DALAM MENINGKATKAN PERKEMBANGAN SOSIAL EMOSIONAL ANAK ATTENTION DEFICIT HIPERACTIVITY DISORDER (ADHD) DI PAUD INKLUSI YOGYAKARTA
}

\author{
Husnuzziadatul Khairi \\ Universitas Islam Negeri Sunan Kalijaga \\ khairieri8@gmail.com
}

\begin{abstract}
ABSTRAK
Penelitian ini bertujuan mendeskripsikan dan membandingkan upaya yang dilakukan oleh guru dalam meningkatkan perkembangan sosial emosional anak dengan gangguan Attention Deficit Hyperactivity Disorder (ADHD) di TK Laboratori Pedagogia UNY dan TK Islam Pelangi Anak Negeri Yogyakarta. Jenis penelitian yang digunakan oleh peneliti dalam penelitian ini adalah deskriptifkomparatif. Sedangkan, Sumber data dari penelitian ini adalah sumber data primer. Sumber data primer yaitu guru, terapis, dan psikolog. Teknik pengumpulan data dengan wawancara, observasi, dan dokumentasi, sedangkan teknik analisis data dilakukan melalui tiga tahapan yaitu reduksi, display, dan verifikasi. Hasil penelitian ini menunjukkan bahwa pertama, upaya guru dalam meningkatkan perkembangan sosial emosional anak ADHD yaitu TK Laboratori Pedagogia UNY melalui tiga tahapan yaitu observasi, intervensi dan penilaian. Sedangkan upaya guru di TK Islam pelangi Anak Negeri Yogyakarta cukup kompleks mulai dari mengobservasi anak, wawancara dengan orang tua, memberikan diagnosa dan Intervensi anak, serta penilaian. Kedua, Persamaan upaya guru dalam meningkatkan perkembangan sosial emosional anak ADHD di dua lokasi penelitian ini adalah sama-sama menggunakan intervensi dalam bentuk ekstingsi, kontak mata, stimulasi, pembiasaan, dan bermain. Sedangkan perbedaannya yaitu, di TK Laboratori Pedagogia UNY guru menggunakan intervensi dalam bentuk time out, perjanjian awal, stimulasi, dan pendekatan perilaku serta bantuan dari para terapis dengan instruksi dari psikolog. Berbeda halnya dengan TK Islam Pelangi Anak Negeri Yogyakarta yang menggunakan intervensi dalam bentuk satiasi, kontak fisik dan terapi okupasi dan wicara. Dikarenakan di TK ini tidak menggunakan psikolog dan terapis, maka guru di sini merangkap sebagai psikolog sekaligus terapis.
\end{abstract}

Kata Kunci: Upaya Guru, Perkembangan Sosial Emosional, ADHD.

Received 30-06-2020; Accepted: 01-07-2020. 
J-SANAK: Jurnal Kajian Anak

(p-ISSN: 2686-5343 |e-ISSN: 2715-7989)

Vol. (1)(2), (Januari-Juni)(2020), (Halaman)(62-77)

DOI: https://doi.org/10.24127/j-sanak.v1i02.233

\begin{abstract}
This study aims to describe and compare the efforts made by the teacher to improve the Development of Social-Emotional Child Attention Deficit Hyperactivity Disorder (ADHD) at the Pedagogical Laboratories UNY Kindergarten and Pelangi Anak Negeri Yogyakarta State Kindergarten. The type of research used by researchers in this study is descriptive-comparative. Meanwhile, the source of data from this study is primary data. Primary data sources are teachers, therapists, and psychologists. Data collection techniques with interviews, and documentation, while data analysis techniques are carried out through three stages, namely reduction, display, and verification. The results of this study indicate that first, the teacher's efforts to improve the social-emotional development of ADHD children, namely the Pedagogical Laboratory of UNY Kindergarten through three stages, namely observation, intervention, and assessment. While the efforts of teachers in Pelangi Anak Negeri Yogyakarta Islamic Kindergarten are quite complex ranging from observing children, interviewing parents, providing child diagnoses and interventions, and evaluating. Second, the equality of teachers' efforts in improving the social-emotional development of ADHD children in the two locations of this study were both using interventions in the form of ecstasy, eye contact, stimulation, habituation, and play. While the differences are, in the Pedagogical Laboratory of UNY Kindergarten teachers use interventions in the form of time out, initial agreement, stimulation, and behavioral approach and assistance from therapists with instructions from psychologists. Unlike the case with the Pelangi Anak Negeri Yogyakarta Kindergarten which uses interventions in the form of satiation, physical contact, and occupational and speech therapy. Because in this kindergarten does not use psychologists and therapists, the teacher here also serves as a psychologist and therapist.
\end{abstract}

Keywords: Teachers Effort, Social-Emotional development, ADHD

\title{
A. PENDAHULUAN
}

Perkembangan sosial emosional anak usia dini merupakan salah satu aspek penting dalam perkembangan anak. Perkembangan sosial emosional berkaitan dengan kapasitas anak untuk mengembangkan self-confidence, trust, dan empathy. Perkembangan sosial emosional yang positif merupakan predictor untuk kesuksesan dalam bidang akademik, kognitif, sosial, dan emosional anak dalam kehidupan selanjutnya (Soetjiningsih, 2018).

Secara rinci dijelaskan oleh Syamsu Yusuf bahwa perkembangan sosial merupakan pencapaian kematangan anak dalam hubungan sosial. Perkembangan sosial dapat juga diartikan sebagai proses belajar untuk menyesuaikan diri terhadap norma-norma kelompok, moral, dan tradisi yang melebur menjadi satu 
J-SANAK: Jurnal Kajian Anak

(p-ISSN: 2686-5343 |e-ISSN: 2715-7989)

Vol. (1)(2), (Januari-Juni)(2020), (Halaman)(62-77)

DOI: https://doi.org/10.24127/j-sanak.v1i02.233

kesatuan yang saling berkomunikasi dan bekerja sama (LN, 2016). Sedangkan emosi menurut Sarlito Wirawan Sarwono menyatakan bahwa setiap keadaan pada diri seseorang yang disertai warna secara efektif baik pada tingkat lemah (dangkal) maupun dalam tingkat luas (mendalam) (Yudrik, 2011). Sehubungan dengan definisi perkembangan sosial emosional ini, maka Departemen Of Children menguraikannya sebagai berikut:

"Social development (being social) how we come to understand ourselves in relation to other, how we make friends, understand the rules of society and behave towards others. Emotional development (having feelings) how we make com to understand our own and others' feelings and develop our ability to 'stand in someone else's shoes' and see things from their point of view, reffered to as empathy (DCSF, 2008)"

Perkembangan sosial emosional adalah wahana untuk membina anak agar dapat mengendalikan emosinya secara wajar dan dapat berinteraksi dengan sesama dan orang lain. Dari beberapa pendapat di atas dapat ditarik kesimpulan bahwa perkembangan sosial emosional adalah perkembangan dimana anak bisa melakukan hubungan dengan orang lain dan dengan cara pengontrolan perasaan terhadap diri sendiri dan orang lain.

Kurang optimal nya tingkat perkembangan sosial emosional rentan terjadi pada anak dengan gangguan attention deficit hyperactivity disorder (ADHD). Melihat bahwa perkembangan sosial emosional adalah salah satu bagian penting dari perkembangan lainnya, maka perlu dilakukannya pemberian layanan atau perlakuan khusus oleh guru kepada anak- anak penyandang disabilitas terutama dengan gangguan attention deficit hyperactivity disorder (ADHD). Tujuan dari diberikannya layanan khusus kepada anak ADHD yaitu agar anak bisa mengontrol emosi yang ada pada dirinya sendiri dan berinteraksi dengan orang yang ada di sekelilingnya, sehingga perkembangan sosial dan emosional yang ada pada diri anak dapat berkembang secara optimal sesuai dengan perkembangan yang dialami anak pada umumnya.

Salah satu bentuk pertolongan terhadap perkembangan sosial emosional anak ADHD adalah dengan memberikan kesempatan kepada anak untuk bergaul dengan anak non disabilitas lainnya dalam sebuah bingkai pendidikan. Pendidikan yang seperti ini sering kita kenal dengan pendidikan inklusi. Pendidikan inklusi adalah pendidikan dengan layanan khusus yang memberikan kesempatan untuk belajar kepada anak berkebutuhan khusus bersama dengan anak-anak pada umumnya sehingga mereka dapat menirukan kegiatan-kegiatan yang dilakukan oleh anak normal lainnya. Peneliti mengetahui bahwa di Yogyakarta ada beberapa lembaga PAUD yang sudah menerapkan layanan bagi anak berkebutuhan khusus.

Copyright (C) 2020, Universitas Muhammadiyah Metro| 64 
J-SANAK: Jurnal Kajian Anak

(p-ISSN: 2686-5343 |e-ISSN: 2715-7989)

Vol. (1)(2), (Januari-Juni)(2020), (Halaman)(62-77)

DOI: https://doi.org/10.24127/j-sanak.v1i02.233

Dalam kajian dan penelitian ini, peneliti melakukan kajian terhadap upaya guru dalam meningkatkan perkembangan sosial emosional anak ADHD di PAUD Inklusi Yogyakarta. Lokasi yang diambil sebagai tempat penelitian yaitu di TK Pedagogia, dan TK Islam Pelangi Anak Negeri.

TK Laboratori Pedagogia terletak di Jl. Bantul No. 50, Gedongkiwo, Mantrijeron, kota Yogyakarta. TK Laboratori Pedagogia sebagai salah satu laboratorium tumbuh kembang anak yang memiliki program unggulan dengan memberikan ruang kepada anak anak difabel untuk belajar bersama dengan teman sebayanya.

Pada kegiatan observasi awal, peneliti melakukan sedikit perbincangan dengan kepala sekolah, berikut hasil wawancara mengenai perkembangan anak dengan gangguan ADHD:

"Dikarenakan sekolah kami adalah salah satu sekolah penyelenggara pendidikan Inklusi, jadi kami menerima anak dengan berbagai keadaan tidak hanya anak ADHD. Namun, dari sekian banyak anak yang mengalami gangguan, anak dengan ADHD yang rentan kami temui. Kami memberikan layanan yang lebih kepada anak dengan berbagai gangguan yang dibantu oleh psikolog, terapis, dan shadow. Dengan penanganan yang tepat dan keadaan seperti lingkungan sekolah yang baik, alhamdulillah keadaan anak-anak ini menjadi lebih baik dari keadaan sebelumnya (Wawancara dengan Kepala Sekolah di TK Laboratori Pedagogia UNY).

TK Islam Pelangi Anak Negeri merupakan salah satu penyedia layanan pendidikan inklusi di kota Yogyakarta. Sekolah ini terletak di Jl. Nitikan Baru No. 09, Pandeyan, Umbulharjo, Kota Yogyakarta, menerima anak dengan berbagai latar belakang sosial, ekonomi, budaya, ras, dan kemampuan. Bentuk inklusi di TK Islam Pelangi Anak Negeri yaitu beberapa isi materi belajar yang disesuaikan dengan kemampuan masing-masing anak, ketersediaan GPK (Guru Pendamping Khusus) dari sekolah, terapi bagi ABK (Anak Berkebutuhan Khusus) murid baru, field trip, kunjungan profesi dan lain-lain. Dalam pelayanan inklusi GPK bertugas untuk membantu anak regular dan ABK ketika mengalami kesulitan dalam pembelajaran sewaktu pembelajaran sedang berlangsung. GPK di TK Islam Pelangi Anak Negeri merupakan guru tetap TK yang disediakan oleh sekolah sendiri.

Sekilas kutipan hasil wawancara yang dilakukan oleh peneliti pada tahap observasi awal, yaitu:

"TK kami ini adalah yayasan bukan TK Negeri seperti TK lainnya, tapi meskipun TK ini adalah milik pribadi, kami berkomitmen untuk menerima dan membantu anak dengan ikhlas tanpa memandang derajat, ekonomi dan 
J-SANAK: Jurnal Kajian Anak

(p-ISSN: 2686-5343 le-ISSN: 2715-7989)

Vol. (1)(2), (Januari-Juni)(2020), (Halaman)(62-77)

DOI: https://doi.org/10.24127/j-sanak.v1i02.233

lainnya. Saya dan suami saya berfikir bahwa kita berkewajiban untuk membantu anak-anak yang bisa dibilang berkebutuhan khusus agar mereka tidak memiliki alasan untuk tidak sekolah. Karena sebenarnya mereka pun seperti kita, butuh pendidikan untuk keberlangsungan hidup mereka ke depannya. Dari pengalaman yang kami miliki dan kepercayaan masyarakat, saya beserta guru-guru yang lain dengan sabar terus memberikan penanganan dan menyediakan tempat yang memberikan kenyamanan kepada mereka (ABK). Dengan kerja keras dan ikhlas yang kami berikan sebagian dari siswa kami yang bisa dibilang ABK, mereka dapat diterima di sekolah umum, seperti di SDN Giwangan. Hal ini menjadi pemicu kita untuk terus melakukan pengembangan diri untuk penanganan anak."

Perkembangan sosial emosional anak ADHD Wawancara yang peneliti lakukan kepada guru di dua lokasi ini tentang konsep perkembangan sosial emosional anak dengan gangguan ADHD ternyata memberikan kesimpulan bagi peneliti bahwa perkembangan sosial emosional anak dengan gangguan ADHD sangat bergantung pada penanganan yang diberikan oleh lingkungan mereka.

Dari hasil observasi awal yang peneliti lakukan di dua lokasi penelitian ini, maka peneliti menemukan hal yang berbeda antara sekolah yang satu dengan yang lainnya dalam pemberian intervensi. Untuk menangani permasalahan yang dialami oleh anak dengan gangguan ADHD dalam perkembangan sosial emosional, maka TK Laboratori Pedagogia UNY memberikan pelayanan yang dilakukan oleh guru berupa pendekatan-pendekatan dan bekerjasama dengan psikolog dan terapis anak. Sedangkan di TK Islam Pelangi Anak Negeri menggunakan berbagai pendekatan yang dilakukan sepenuhnya oleh guru tanpa ada bantuan dari psikolog dan terapis. Guru meningkatkan perkembangan anak ADHD dengan dibekali pelatihan-pelatihan penanganan ABK dan pengalamanpengalaman yang sudah dilakukan sebelum-sebelumnya.

Dikarenakan bentuk pelayanan dan penanganan yang didapatkan oleh anak berbeda, maka perbedaan ini tentu saja akan berdampak pada tingkat perkembangan sosial emosional anak. Ha ini menjadi alasan yang menarik untuk peneliti melakukan pengkajian lebih jauh dengan tema "Upaya Guru Dalam Meningkatkan Perkembangan Sosial Emosional Anak ADHD Di PAUD Inklusi Yogyakarta" dengan mengambil lokasi di 2 tempat yaitu TK Laboratori Pedagogia dan TK Islam Pelangi Anak Negeri. Alasan pertama, peneliti ingin mengetahui bagaimana perkembangan dan upaya yang dilakukan oleh guru terhadap perkembangan sosial emosional anak ADHD di PAUD Inklusi Yogyakarta. Kedua, peneliti ingin melakukan komparasi upaya guru dalam meningkatkan perkembangan sosial emosional anak ADHD di TK Laboratori 
J-SANAK: Jurnal Kajian Anak

(p-ISSN: 2686-5343 |e-ISSN: 2715-7989)

Vol. (1)(2), (Januari-Juni)(2020), (Halaman)(62-77)

DOI: https://doi.org/10.24127/j-sanak.v1i02.233

Pedagogia UNY yang dibantu oleh psikolog dan terapis dengan TK Islam Pelangi Anak Negeri Yogyakarta yang mengandalkan keyakinan dan pengalaman guru dan kepala sekolah, serta mengetahui perubahan dari upaya yang dilakukan oleh guru.

Dari hasil pemaparan permasalahan di atas, maka peneliti memfokuskan untuk mengkaji persamaan dan perbedaan upaya guru dalam meningkatkan perkembangan sosial emosional anak ADHD di (PAUD Inklusi Yogyakarta) TK Laboratori Pedagogia UNY dengan TK Islam Pelangi Anak Negeri Yogyakarta

\section{B. METODOLOGI}

Metodologi yang digunakan oleh peneliti dalam penelitian ini adalah jenis penelitian kualitatif (Moleong, 2013) dengan pendekatan deskriptif-komparatif (Sugiyono, n.d.). Sedangkan, Sumber data dari penelitian ini adalah sumber data primer. Sumber data primer berjumlah 9 orang, 5 orang (4 orang guru dan 1 psikolog) di TK Laboratori Pedagogia UNY dan 4 orang ( 3 orang guru dan kepala sekolah sebagai pelatih guru) di TK Islam Pelangi Anak Negeri Yogyakarta. Teknik pengambilan sampling yang digunakan oleh peneliti dalam memilih mereka sebagai sumber data primer dengan menggunakan purposive sampling, hal ini dikarenakan mereka adalah salah satu pemegang kendali dalam proses pembelajaran di sekolah dan mengetahui bagaimana perkembangan anak dari waktu ke waktu. Sedangkan data sekunder adalah data yang didapatkan melalui kepala sekolah, staff sekolah, buku-buku dan sumber lain yang relevan dengan penelitian ini. Teknik pengumpulan data yang peneliti gunakan adalah dengan wawancara, observasi, dan dokumentasi, sedangkan teknik analisis data dilakukan melalui tiga tahapan yaitu reduksi, display, dan verifikasi.

\section{PEMBAHASAN}

\section{Persamaan Bentuk Upaya Guru Terhadap Perkembangan Sosial Emosional ADHD Di TK Laboratori Pedagogia UNY dan TK Islam Pelangi Anak Negeri Yogyakarta}

Untuk mencapai tujuan yang sudah ditargetkan, maka sekolah inklusi memberikan pelayanan lebih kepada anak ADHD dalam rangka meningkatkan perkembangan sosial emosional nya agar dapat mengimbangi anak normal. Berangkat dari teori yang peneliti paparkan di atas, maka secara umum dua lokasi penelitian ini sudah memberikan gambaran atas realisasi penanganan guru terhadap perkembangan anak ADHD. Bentuk penanganan yang diberikan terinci 
J-SANAK: Jurnal Kajian Anak

(p-ISSN: 2686-5343 |e-ISSN: 2715-7989)

Vol. (1)(2), (Januari-Juni)(2020), (Halaman)(62-77)

DOI: https://doi.org/10.24127/j-sanak.v1i02.233

dalam setiap bagian penting yang dilakukan oleh guru. Poin utama dalam teori adalah bagaimana penerapan dari keterampilan manajemen sosial dan manajemen keterampilan diri. Dua poin besar ini dapat digambarkan dari setiap tindakantindakan kecil dalam mengaplikasikannya dengan anak. Contoh kecil bagian dari manajemen keterampilan sosial adalah dengan menatap lawan bicara dan duduk tenang, di dalam penemuan peneliti keterampilan sosial dalam bentuk ini bisa ditemukan dalam pendekatan kontak mata, karena dengan menggunakan kontak mata maka anak akan mampu berbicara dengan guru, sehingga bisa membuat anak lebih tenang dalam bertindak.

Sedangkan latihan dalam manajemen keterampilan diri yaitu dengan latihan ulang atribusi yang senada dengan penanganan yang dilakukan oleh guru melalui pendekatan stimulasi dan pembiasaan. Latihan ulang atribusi membuat anak menjadi percaya diri hingga mampu melakukan sesuatu, sama halnya dengan dua pendekatan tadi (stimulasi dan pembiasan), stimulasi digunakan agar anak tidak merasa canggung dalam berinteraksi dengan guru dan teman-teman lainnya sehingga muncul rasa percaya diri, kemudian setelah rasa percaya diri tumbuh maka terus dipupuk dengan melakukan pembiasaan-pembiasaan. Pendekatanpendekatan ini cukup untuk mengiringi teori-teori yang ada dalam penelitian ini.

Di TK Laboratori Pedagogia UNY dan TK Islam Pelangi Anak Negeri Yogyakarta guru memiliki beberapa kesamaan dalam penanganan anak ADHD yaitu menggunakan cara bermain, stimulasi, dan pembiasaan sebagai bentuk upaya yang mumpuni untuk memaksimalkan perkembangan sosial emosional anak ADHD. Cara-cara ini digunakan sesuai dengan kebutuhan anak didik. Berikut penjelasan mengenai cara-cara yang diterapkan:

\section{a) Kontak Mata}

Di TK Laboratori Pedagogia UNY, kontak mata dilakukan dengan tujuan untuk memberikan sedikit ketenangan kepada anak. Hal ini dilakukan sebelum guru memberikan instruksi kepada anak untuk melakukan sebuah kegiatan. Guru meminta anak untuk menatap matanya, kemudian mencoba untuk berbicara, apabila perkataan guru belum bisa didengarkan itu artinya anak belum fokus dan akan terus coba dilakukan sampai anak benar-benar bisa tenang. Hal yang sama dilakukan di TK Islam Pelangi Anak Negeri Yogyakarta guru meminta kepada anak untuk mencoba fokus terhadap apa yang dikatakan, namun ketika anak tidak bisa melakukan kontak mata, guru langsung merangkul anak dan mencoba menatap anak dengan keadaan sedikit agak memaksa sehingga pada akhirnya anak fokus dan dapat memulai pembelajaran seperti biasa dengan anak-anak lain di dalam kelas. 
J-SANAK: Jurnal Kajian Anak

(p-ISSN: 2686-5343 le-ISSN: 2715-7989)

Vol. (1)(2), (Januari-Juni)(2020), (Halaman)(62-77)

DOI: https://doi.org/10.24127/j-sanak.v1i02.233

\section{b) Bermain}

Bermain digunakan di dua lokasi penelitian ini (TK Laboratori Pedagogia UNY dan TK Islam Pelangi Anak Negeri Yogyakarta) dan hampir di semua gangguan baik itu anak yang mengalami gangguan ADHD, autis, Down syndrome, dan lainnya. Cara ini digunakan sebagai stimulus untuk meningkatkan perkembangan sosial emosional anak ADHD baik itu di dalam maupun di luar kelas.

Masa kanak-kanak adalah salah satu masa bermain. Artinya anak akan lebih cepat mengalami perubahan dalam berbagai aspek apabila kita membimbingnya dengan cara bermain. Seperti yang kita ketahui bahwa anak dapat berkembang melalui interaksi dengan lingkungan. Salah satu bentuk interaksi dengan lingkungan adalah dengan bermain. Bermain dapat dijadikan sebagai bentuk terapi yang dapat memberikan kebebasan pada anak untuk mengekspresikan diri mereka melalui penggunaan mainan dalam aktivitas bermain guna untuk mengembangkan kemampuan yang mereka miliki.

Bermain tidak hanya sebagai wujud dari perasaan ingin bahagia seorang anak, melainkan sebagai cerminan kemampuan sosial emosional anak, serta sebagai media untuk belajar. Ketika anak bermain maka tidak hanya memberikan dampak pada perkembangan sosial emosional nya, tetapi juga pada perkembangan fisik dan intelektual mereka. Bermain Menurut pendapat Campbell dan Glaser, bermain sama dengan bekerja pada orang dewasa, dan merupakan aspek terpenting dalam kehidupan anak, serta salah satu cara yang paling efektif untuk menurunkan stress dan meningkatkan kesehatan mental dan emosional pada anak.

Demikian pula halnya dengan pendapat Soetjiningsih, anak bermain pada dasarnya untuk memperoleh kesenangan sehingga tidak merasa jenuh. Bermain tidak hanya sekedar mengisi waktu, tetapi kebutuhan anak sebagaimana halnya makan, self-care, dan kasih sayang. Hal yang paling utama adalah untuk meningkatkan kemampuan anak dalam memahami bahasa, mengembangkan kemampuannya untuk berkomunikasi dan berinteraksi dengan orang lain di sekitarnya. Permainan interaktif didasarkan atas pemahaman akan pentingnya pragmatis dalam komunikasi.

Perkembangan sosial emosional ditandai dengan kemampuan berinteraksi dengan lingkungannya dan pengendalian diri. Anak akan belajar memberi dan menerima. Bermain dengan orang lain akan membantu anak untuk mengembangkan hubungan sosial emosional anak dan belajar memecahkan masalah dari hubungan sosial tersebut. 
J-SANAK: Jurnal Kajian Anak

(p-ISSN: 2686-5343 le-ISSN: 2715-7989)

Vol. (1)(2), (Januari-Juni)(2020), (Halaman)(62-77)

DOI: https://doi.org/10.24127/j-sanak.v1i02.233

\section{c) Stimulasi}

Tidak hanya bermain yang dijadikan sebagai faktor utama dalam meningkatkan perkembangan sosial emosional, tetapi juga didukung dengan kegiatan di dalam pembelajaran yang berupa stimulasi. Stimulasi yang diberikan guru di TK Laboratori Pedagogia UNY diawali dengan penyatuan dunia guru dengan dunia anak dan tidak membeda-bedakan anak yang satu dengan anak yang lain (Wawancara dengan kepala sekolah di TK Islam Pelangi anak Negeri Yogyakarta). Sementara itu stimulasi di TK Islam Pelangi Anak Negeri Yogyakarta dalam bentuk kecintaan dan pemberian kasih sayang kepada anak. Mencintai dan menerima, tidak menghakimi, menghargai setiap usaha yang dilakukan oleh anak adalah hal yang sangat berharga untuk perkembangan anak di masa yang akan dating (Wawancara dengan guru di TK Laboratori Pedagogia UNY).

Daerah stimulasi untuk anak usia dini diantaranya adalah gerakan mengontrol tubuh. Kekuatan dan keseimbangan ini dapat membantu anak bergerak, melakukan sesuatu, bermain dan bekerja, menggunakan tangan untuk meningkatkan kemampuan mengontrol tangan dan koordinasi antara tangan dan penglihatan sehingga memungkinkan anak mengembangkan banyak keterampilan. Panca indera terutama pendengaran, penglihatan, dan perasaan ini akan menolong anak mengenali dan mengadakan respon di dunia sekitarnya. Kemampuan berkomunikasi terdiri dari mendengarkan, mengerti percakapan, dan belajar berbicara, interaksi dengan orang lain, tersenyum, bermain, berprilaku yang baik dan belajar bergaul dengan orang lain, kegiatan-kegiatan pokok untuk hidup sehari-hari, makan, minum, berpakaian, buang air kecil dan besar. Keterampilan ini dapat membantu anak untuk menjadi mandiri, memperhatikan, berfikir dan mengerjakan sesuatu untuk belajar bagaimana membuat pemikiran dan keputusan yang bijaksana.

\section{d) Pembiasaan}

Pembiasaan adalah upaya untuk self-care atau menolong diri sendiri dengan cara menyelesaikan aktivitas secara mandiri. Umumnya tujuan orang tua memasukkan anaknya dalam dunia pendidikan adalah membuat anak menjadi sosok yang mandiri, tidak bergantung kepada orang tua dan bertanggung jawab. Dari hasil observasi yang telah dilakukan di dua lembaga Taman kanak-kanak ini, maka bentuk pembiasaan yang ditanamkan terdiri dari melepas kaos kaki, melepas celana, memakai celana, menaruh tempat makan dan minum di rak yang sudah 
J-SANAK: Jurnal Kajian Anak

(p-ISSN: 2686-5343 |e-ISSN: 2715-7989)

Vol. (1)(2), (Januari-Juni)(2020), (Halaman)(62-77)

DOI: https://doi.org/10.24127/j-sanak.v1i02.233

disediakan, minum dengan cara duduk, makan di atas meja, melepaskan mengenakan baju, toilet training untuk buang air besar dan kecil. Satu poin yang membuat TK Islam Pelangi Anak Negeri Yogyakarta dikenal yaitu pembiasaan shalat dhuha dan bacaan surat-surat pendek yang dilakukan sebelum memulai proses pembelajaran. Salah satu karakteristik terpenting dari pembiasaan adalah saat komunitas yang kohesif, menerima dan responsif terhadap kebutuhan individual siswa.

Selain kesamaan penggunaan pendekatan di atas, dua sekolah ini juga samasama menggunakan teknik ekstingsi dalam menangani perkembangan sosial emosional anak dengan gangguan ADHD. Penggunaan teknik ini memberikan dampak positif kepada anak dan guru, anak tidak lagi manja dengan terus diikuti keinginannya terlebih itu anak menginginkan hal yang kurang baik untuk mereka yang sesuai dengan usia dan kebutuhan mereka.

\section{Perbedaan Bentuk Upaya Guru Terhadap Perkembangan Sosial Emosional Anak ADHD Di TK Laboratori Pedagogia UNY dan TK Islam Pelangi Anak Negeri Yogyakarta}

Masing-masing sekolah tidak selalu sama sehingga memiliki perbedaan dalam berbagai bidang, contoh kecil dari perbedaan itu adalah dari upaya-upaya yang dilakukan oleh guru dalam meningkatkan perkembangan sosial emosional anak ADHD. Ada beberapa perbedaan yang peneliti temui antara sekolah yang satu dengan yang lainnya dan memiliki keunikan tersendiri. Perbedaan-perbedaan upaya itu antara lain teknik satiasi, time out, pendekatan perilaku, perjanjian awal (kontrak belajar), kontak fisik, terapi okupasi dan wicara. Berikut uraian dari perbedaan-perbedaan yang dimaksud.

\section{a) Satiasi}

TK Islam Pelangi Anak Negeri Yogyakarta menggunakan teknik ini sebagai langkah awal menenangkan anak dengan tujuan menguras tenaga anak agar dapat lebih berkonsentrasi dengan pembelajaran di dalam kelas. Satiasi memang sangat cocok digunakan untuk menangani anak dengan gangguan ADHD. Tidak sama halnya dengan TK Laboratori Pedagogia UNY, di TK ini guru tidak menggunakan teknik satiasi di dalam maupun di luar kelas, dikarenakan anak dengan gangguan ADHD harus tetap mengikuti proses pembelajaran dari awal sama dengan anak lainnya. Adapun cara yang dilakukan dengan teknik ini diserahkan kepada pihak terapis untuk melakukan terapi sesuai dengan jadwal yang ditentukan. 
J-SANAK: Jurnal Kajian Anak

(p-ISSN: 2686-5343 le-ISSN: 2715-7989)

Vol. (1)(2), (Januari-Juni)(2020), (Halaman)(62-77)

DOI: https://doi.org/10.24127/j-sanak.v1i02.233

\section{b) Time out}

Penggunaan teknik Time out oleh guru di TK Laboratori Pedagogia UNY lebih cenderung bertujuan untuk menenangkan anak dari kondisi yang tidak diinginkan dan membuat anak agar tetap konsentrasi dengan kegiatan yang ada atau instruksi yang disampaikan oleh guru. Penerapan teknik time out tidak terlalu sering dilakukan oleh guru, dikarenakan bisa saja anak merasa sangat tidak nyaman dengan kondisi yang mereka jalani. Berbeda dengan TK Islam Pelangi Anak Negeri Yogyakarta, guru tidak menerapkan teknik ini. Guru lebih memberikan perhatian kepada anak agar anak merasa nyaman dengan keadaan mereka dan bisa keluar dari tingkah laku yang memang tidak diharapkan. Mereka kembali ke prinsip sebelumnya yang memberikan kesempatan seluas-luasnya kepada anak untuk mengembangkan diri mereka sesuai dengan usia anak.

\section{c) Perjanjian Di Awal (Kontrak Belajar)}

Pendekatan ini diterapkan di TK Laboratori Pedagogia UNY dikarenakan akan berdampak pada kebaikan anak dan orang lain. Dengan dibuatnya perjanjian di awal maka anak akan sedikit lebih bisa mengontrol setiap tindakan yang mereka lakukan, oleh karena itu mereka akan memposisikan dirinya dengan sebaik mungkin untuk menghindari pelanggaran perjanjian. Menurut Geoff Kewley dan Pauline Latham dalam Mulyono, cara ini disebut dengan Teknik kontrak. Teknik ini dapat menjadi strategi yang bermanfaat untuk anak didik, kesepakatan yang dibuat yang berhubungan dengan tingkah laku yang bermasalah. Kontrak ini akan menjelaskan bagaimana si anak didik akan bertindak dan bertingkah laku berbeda, apa yang akan diterima sebagai ganjarannya (Mulyono, 2011).

Berbeda halnya di TK Islam Pelangi Anak Negeri Yogyakarta, penerapan pendekatan itu belum nampak dari penelitian di lapangan. Dikarenakan untuk perjanjian awal apabila diterapkan akan menjadi sebuah bentuk penekanan untuk anak sehingga guru tidak bisa dengan bebas memberikan penanganan kepada anak sesuai dengan masalah yang dibutuhkan saat itu.

\section{d) Pendekatan Perilaku}

Pendekatan ini adalah salah satu bentuk pendekatan yang dapat membangun kemampuan sosial anak, dan dapat mengurangi serta menghilangkan tingkah laku yang kurang wajar pada anak. Anak belajar dengan berbagai cara antara lain melalui imitasi, melakukan sesuatu atau mencoba dan mengalami. Lingkungan menyediakan sesuatu yang dibutuhkan anak, dan anak akan memanfaatkan apa 
J-SANAK: Jurnal Kajian Anak

(p-ISSN: 2686-5343 le-ISSN: 2715-7989)

Vol. (1)(2), (Januari-Juni)(2020), (Halaman)(62-77)

DOI: https://doi.org/10.24127/j-sanak.v1i02.233

yang ditawarkan oleh lingkungan. Orang dewasa dapat melatih, menjelaskan, dan mengoreksi anak, atau menunjukkan sesuatu kepada anak. Oleh karena itu yang dapat dilakukan oleh guru atau orang dewasa adalah membantu anak agar terlibat dan terdorong mencoba dan mengalami sebuah kegiatan. Anak mempunyai bakat atau kemampuan yang telah dibawa sejak lahir, namun bakat atau kemampuan tersebut tidak akan berkembang apabila tidak memperoleh rangsangan dari lingkungannya.

Para guru di TK Laboratori Pedagogia UNY akan memberikan anak reward apabila anak dapat berkonsentrasi dengan baik sehingga dapat menjawab pertanyaan dan mengikuti kegiatan selama proses belajar yang diinstruksikan oleh guru. Pemberian reward ini bisa saja dalam bentuk stiker atau bisa juga dalam bentuk pujian-pujian, sehingga anak merasa lebih bahagia dan bersemangat untuk mengulangi hal yang sama di hari berikutnya.

Sedangkan punishment diberikan apabila anak melanggar kontrak yang sudah dibuat sebelumnya. Hukuman yang diberikan dalam bentuk yang sederhana yang tidak menyakiti fisik maupun batin sang anak. Dalam memberikan hukuman guru juga harus lebih faham bagaimana kondisi anak, dikarenakan apabila anak ADHD diberikan hukuman yang berat maka mereka akan semakin menjadi-jadi dalam bertingkah.

Teknik ini sesuai dengan apa yang diungkapkan oleh Geoff Kewley dan Pauline Latham bahwa memberikan penghargaan dan hukuman bertujuan agar anak lebih bersemangat dalam proses pembelajaran, penghargaan yang lebih menguatkan dan bermakna akan lebih efektif dibandingkan hukuman. Yang perlu diketahui apabila guru memberikan hukuman yang cukup ekstrim kemungkinan anak akan berhenti mencoba menjadi baik.

Sedangkan perlakuan dalam bentuk pendekatan perilaku ini juga tidak dianggap sebagai sebuah pendekatan yang perlu digunakan karena merangkap dalam pendekatan pembiasaan pada anak di TK Islam Pelangi Anak Negeri Yogyakarta.

\section{e) Pendekatan Kontak Fisik}

Menjadi sebuah penanganan yang penting bagi TK Islam Pelangi Anak Negeri Yogyakarta untuk melakukan kontak fisik. Kontak fisik adalah salah satu bentuk penanganan yang dapat memberikan ketenangan dan kenyamanan untuk anak. Kontak fisik juga dilakukan oleh guru ketika anak ADHD terlihat kurang konsentrasi. Dengan kontak fisik guru dapat menegur tingkah anak yang kurang wajar, ini dilakukan dengan cara menepuk bahu anak, bisa juga dilakukan dengan 
J-SANAK: Jurnal Kajian Anak

(p-ISSN: 2686-5343 le-ISSN: 2715-7989)

Vol. (1)(2), (Januari-Juni)(2020), (Halaman)(62-77)

DOI: https://doi.org/10.24127/j-sanak.v1i02.233

mengelus-elus kepala anak. Cara ini bertujuan untuk mengembalikan control diri pada anak yang ada di TK Islam Pelangi Anak Negeri Yogyakarta dan dianggap menjadi sebuah terapi.

Sedangkan apabila peneliti melihat kontak fisik yang dilakukan oleh para guru di TK Laboratori Pedagogia UNY bukan dalam bentuk pendekatan. Karena kontak fisik ini dilakukan secara merata kepada anak, tidak hanya anak yang mengalami gangguan saja dan tidak terlalu sering.

\section{f) Terapi Okupasi Dan Terapi Wicara}

Dikarenakan di TK Islam Pelangi Anak Negeri Yogyakarta tidak menggunakan terapis dan psikolog, maka guru langsung turun tangan ntuk menangani anak. Penanganan yang diberikan guru pada anak yang mengalami ADHD adalah jenis terapi okupasi, yakni terapi fisik anak dengan cara menyeimbangkan gerak motorik kasar dan halus.

Terapi okupasi diperlukan untuk perkembangan motorik, sebagian anak ADHD mempunyai perkembangan motorik yang kurang baik. Gerak-geriknya kasar dan kurang luwes bila dibandingkan dengan anak lain seumurannya. Anakanak perlu diberi bantuan terapi okupasi untuk membantu menguatkan, memperbaiki koordinasi, dan membuat otot halus nya bisa terampil. Otot jari tangan misalnya, sangat penting dikuatkan dan dilatih supaya anak bisa menulis dan melakukan semua hal yang membutuhkan keterampilan otot jari tangannya.

Terapi okupasi menggunakan aktifitas okupasi anak untuk meningkatkan keterampilan. Beberapa keterampilan okupasi anak diantaranya adalah keterampilan regulasi dan control diri, mengembangkan keterampilan motorik kasar dan halus sebagai koordinasi gerak, mengembangkan keterampilan berkomunikasi, dan interaksi sosial, meningkatkan ketrampilan bantu diri, dan mengembangkan konsep diri agar anak bisa mengontrol dan memimpin dirinya sendiri.

Selain itu hambatan jenis ADHD biasanya memang menyerang pada anak yang hiperaktif dan sulit untuk diajak berkomunikasi. Kemampuan mengikuti perintah duduk di kursi, kontak mata saat dipanggil namanya, memberi respon terhadap perintah "tangan di bawah" atau "lipat tangan" sebagaimana contoh terapis (Wawancara dengan guru di TK Islam Pelangi Anak negeri Yogyakarta).

Dikarenakan kebutuhan anak mengalami ADHD sulit diajak berkomunikasi maka berdampak pada kurangnya komunikasi, sehingga guru juga melakukan terapi wicara dengan tujuan untuk melatih perkembangan bahasa anak. Kedua 
J-SANAK: Jurnal Kajian Anak

(p-ISSN: 2686-5343 le-ISSN: 2715-7989)

Vol. (1)(2), (Januari-Juni)(2020), (Halaman)(62-77)

DOI: https://doi.org/10.24127/j-sanak.v1i02.233

terapi ini saling berkaitan karena saling mendukung perkembangan ADHD. Selain itu, hambatan jenis ADHD biasanya memang menyerang pada anak hiperaktif dan sulit untuk diajak berkomunikasi. Perkembangan setiap anak ADHD berbeda, baik itu perkembangan karakter, perkembangan bahasa, bahkan cara perkembangannya. Tetapi kebutuhan ADHD hampir sama. Anak ADHD jika suka pada sesuatu, dia merasa menikmati nya. Oleh karena itu, tugas guru adalah sebagai fasilitator.

Yang perlu diperhatikan oleh seorang guru yang merangkap langsung sebagai terapis adalah hal-hal sebagai berikut:

1) Memberi waktu dan kesempatan kepada setiap anak untuk melihat masalahnya secara jelas tanpa dengan cepat-cepat memberi bantuan.

2) Tidak terlalu cepat memberi kegiatan, tunggu sampai anak siap dan mengenal terapis dengan baik.

3) Kalau anak sampai menolak kehadiran terapis, tidak cepat-cepat putus asa, kemungkinan ada dua hal yaitu belum waktunya ikut campur atau terlalu dini, belum ada rasa aman dan sesuatu yang masih baru, anak lebih cenderung untuk menolak.

4) Masalah, harus jelas, perintah ringkas, singkat, dan cukup terdengar.

5) Kalau situasinya sudah menyenangkan biasanya permainan harus bervariasi dan dilakukan dengan konsisten.

6) Kalau terjadi sesuatu tingkah laku yang ekstrim, dikerjakan dengan tenang dengan memberikan barang yang disukai anak (Saragi, 1977).

Menjadi hal yang kontra bagi para guru di TK Laboratori Pedagogia UNY untuk melakukan terapi, karena yang melakukan terapi adalah terapis. Pengetahuan, dan pelatihan tentang terapi diberikan kepada guru-guru di TK ini, namun tidak untuk menjadi seorang terapis. Guru bertugas di dalam kelas untuk membantu meningkatkan perkembangan anak dan menggali potensi yang mereka miliki. 
J-SANAK: Jurnal Kajian Anak

(p-ISSN: 2686-5343 le-ISSN: 2715-7989)

Vol. (1)(2), (Januari-Juni)(2020), (Halaman)(62-77)

DOI: https://doi.org/10.24127/j-sanak.v1i02.233
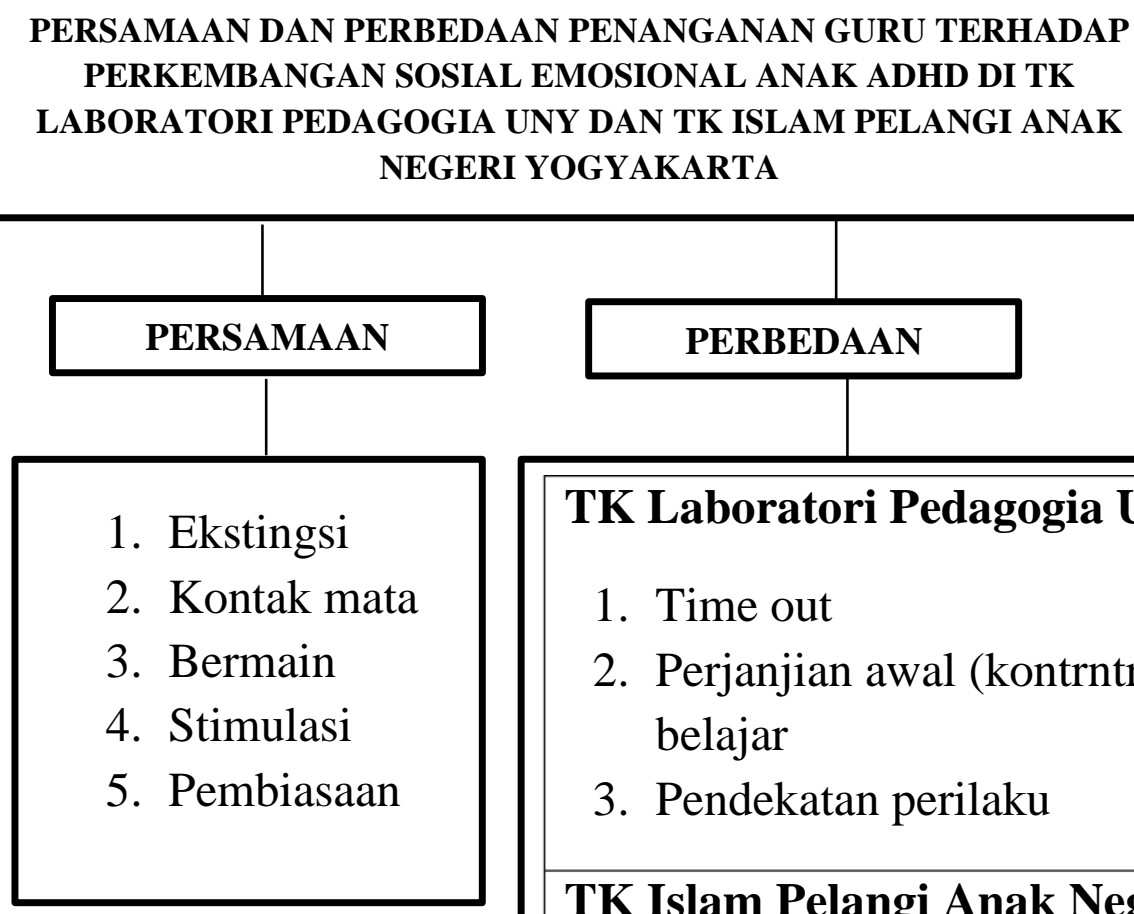

TK Laboratori Pedagogia UNY

1. Time out

2. Perjanjian awal (kontrntrak belajar

3. Pendekatan perilaku

TK Islam Pelangi Anak Negeri Yogyakarta

1. Stiasi

2. Kontak fisik

3. Terapi okupasi dan wicara

\section{KESIMPULAN}

Berdasarkan hasil penelitian dan analisis data yang peneliti lakukan mengenai upaya guru dalam meningkatkan perkembangan sosial emosional anak Attention Deficit Hyperactivity Disorders (ADHD) di PAUD Inklusi Yogyakarta, maka dapat disimpulkan sebagai berikut:

1. Terkait dengan upaya yang dilakukan guru guna meningkatkan Perkembangan Sosial Emosional Anak ADHD dapat dikatakan cukup kompleks dan sistematis, dikarenakan di TK Laboratori Pedagogia UNY melalui tiga tahapan yaitu observasi, intervensi dan penilaian. Masing-masing tahapan itu memiliki kegiatan yang penting terutama pada tahap intervensi. Sedangkan upaya guru dalam meningkatkan perkembangan sosial Emosional Anak ADHD di TK Islam pelangi Anak Negeri Yogyakarta cukup kompleks 
J-SANAK: Jurnal Kajian Anak

(p-ISSN: 2686-5343 |e-ISSN: 2715-7989)

Vol. (1)(2), (Januari-Juni)(2020), (Halaman)(62-77)

DOI: https://doi.org/10.24127/j-sanak.v1i02.233

mulai dari mengobservasi anak yang dilakukan pada awal pertemuan, kemudian wawancara dengan orang tua untuk mendapatkan informasi tentang perkembangan anak selama di rumah, memberikan diagnosa dan Intervensi, serta penilaian dilakukan dalam bentuk catatan anekdot.

2. Sebagai sekolah inklusi ada beberapa Persamaan dan perbedaan intervensi yang dilakukan oleh guru dalam meningkatkan perkembangan sosial emosional anak ADHD di (PAUD Inklusi Yogyakarta) TK Laboratori Pedagogia UNY dengan TK Islam Pelangi Anak Negeri Yogyakarta. Persamaan intervensi yang dilakukan kepada anak adalah intervensi dalam bentuk teknik ekstingsi kontak mata, stimulasi, bermain, dan pembiasaan. Perbedaan menjadi salah satu nilai positif dari masing-masing sekolah dalam rangka terus mengembangkan dan memajukan diri agar dapat menarik perhatian masyarakat. Dimana TK Laboratori Pedagogia UNY menggunakan professional dan guru untuk membantu perkembangan anak. Guru mengintervensi anak dalam bentuk time out, perjanjian awal, dan pendekatan perilaku. Sedangkan yang menjadi pemikat dari TK Islam Pelangi Anak Negeri Yogyakarta di hati masyarakat adalah guru melakukan semua sendiri, guru melakukan tugas di dalam kelas dan merangkap menjadi yang professional. Hal lain yang membedakan sekolah ini dengan sekolah lain adalah intervensi yang dilakukan oleh guru dalam bentuk satiasi, kontak fisik dan terapi okupasi dan wicara.

\section{E. DAFTAR PUSTAKA}

Department of Children, School And Families (DCSF). 2008. Social And Emotional Aspects Of Development Guidance For Practitioners Working In The Early Years Foundation Stage. London: DCSF Publications.

LN, H. S. Y. (2016). Psikologi perkembangan anak \& remaja. Remaja Rosdakarya.

Moleong, L. (2013). J. 2007. Metodologi Penelitian Kualitatif, 4-10.

Mulyono, M. (2011). Strategi pembelajaran: Menuju efektifitas pembelajaran di abad global. UIN-Maliki Press.

Soetjiningsih, C. H. (2018). Perkembangan Anak Sejak Pembuahan Sampai dengan Kanak-Kanak Akhir: Seri Psikologi Perkembangan. Prenada Media.

Sugiyono, P. (n.d.). Dr. 2010. Metode Penelitian Kuantitatif, Kualitatif, Dan $R \& D$. Bandung: CV Alfabeta.

Yudrik, J. (2011). Psikologi Perkembangan. Jakarta. Kencana. 